\title{
A Brief Report on the State of U.S. Agriculture and Fisheries
}

By: $\underline{\text { Susan Andreatta }}$

Andreatta, Susan. 2011 A Brief Report on the State of U.S. Agriculture and Fisheries. Journal of Culture, Agriculture, Food and Environment. (CAFE). 33(2):107-116.

Made available courtesy of American Anthropology Association \& Wiley-Blackwell: http://onlinelibrary.wiley.com/doi/10.1111/j.2153-9561.2011.01054.x/full

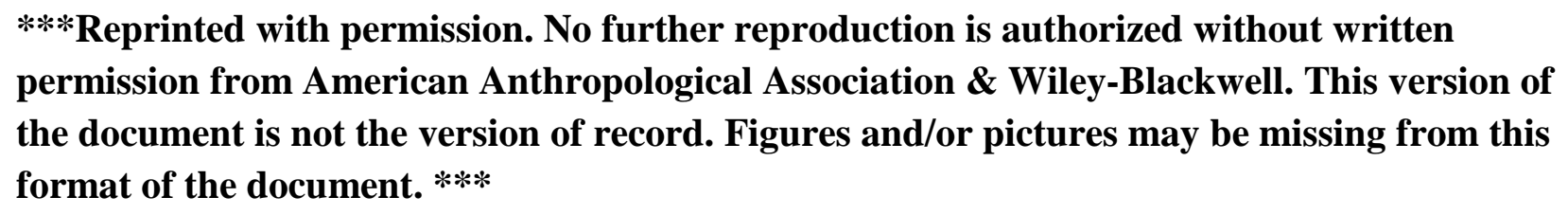
permission from American Anthropological Association \& Wiley-Blackwell. This version of the document is not the version of record. Figures and/or pictures may be missing from this format of the document. ***

\begin{abstract}
:
This brief report on the state of U.S. agriculture and fisheries emphasizes challenges and opportunities for small-scale producers in the agri-aqua food system, including current directions for farming and fisheries.
\end{abstract}

Keywords: United States | farmers | fishermen | consumers |direct marketing

\section{Article:}

Not a day goes by without something in the media discussing food access, food security, food safety, or sustainability — the good and the not so good—in the U.S. food system. These topics mean different things to different groups, but because of the universal need for food, more people are becoming more invested in their food system. For some, the discussion and action revolves around the industrial nature of the food system, while for others, the focus is on smallscale producers or harvesters, or on equitable access to fresh, local commodities by consumers, especially low-income households and those living in food deserts. Schlosser (2011:2) characterizes America's food system in the following way: The "current system of food production - overly centralized and industrialized, overly controlled by a handful of companies, overly reliant on monoculture, pesticides, chemical fertilizers, chemical additives, genetically modified organisms, factory farms, government subsidies and fossil fuels-is profoundly undemocratic." A food system that is heavily influenced by Monsanto, Walmart, and McDonalds creates political, economic, and environmental challenges that threaten the survivability and viability of local producers and harvesters, farm workers, and migrant laborers in a global economy. For anthropologists, who tend to engage in community-based research, this brief report on the state of U.S. agriculture and fisheries will emphasize challenges and opportunities for small-scale producers in the agri-aqua food system. 
It is no surprise that U.S. industrial agriculture leads the world in field production yields, based on the use of conventional fertilizers, insecticides, fungicides, and genetically modified seeds. These inputs, coupled with high-volume harvests, contribute substantially to transnational corporations' (TNCs) lead in the manufacturing of American industrial, processed foods found on supermarkets shelves and consumers' plates. Experts believe that such processed foods, with their added sugars (fructose) and salts (sodium), have contributed to the rising rates of obesity and diabetes in the United States (Centers for Disease Control and Prevention [CDC] 2011a; Nestle 2002). Approximately one third (33.8 percent) of U.S. adults are obese and 17 percent (or 12.5 million) of children between the ages of 2-19 years are obese (CDC 2011a). One need not be a molecular biologist or a home economics teacher to recognize that over the years, families have been drifting away from cooking with natural, raw products to microwaving and reheating processed, precooked foods, and eating out at fast-food establishments (Gabaccia 1998; Schlosser 2011).

Two current examples illustrate the role TNCs play in influencing the industrial agri-aqua food system by what it supplies and, by extension, what the public has to purchase. In 2010, Del Monte began offering single bananas wrapped in a transparent plastic bag and marketed as "The Natural Energy Snack on the Go.” It is most curious that at a time when landfills are running out of space and the public is asked to be mindful of the excess rubbish they generate, that someone thought a banana with its skin on was not clean enough for public consumption or that the fruit was vulnerable unpackaged, therefore making it necessary to package a banana for some supermarket chains. And in 2011, McDonald's jumped on the bandwagon of more "healthy eating” by modifying its Happy Meal of a hamburger, fries, and soft drink. The new Happy Meal is to include apple slices and shorter French fries with lower sodium content. The list of the new food products that comes out annually for supermarkets and fast-food restaurant chains is endless. It appears from these examples that the food industry is making their value-added products available and suggesting these are items the public needs and desires. But are they? We should continue to question this marketing and eating approach on many levels and some people are.

There are numerous examples of resistance in the United States to the agri-aqua food system among farmers, fishermen, and consumers (as eaters, growers, and fishers). In fact, for several decades, these food producers, harvesters, and consumers have been the leaders in food movements and in the creation of food communities. Current interest in food communities has come about with the increased attention paid by consumers who desire foods that are harvested from local farms and local waters by local producers. Interest has grown with the public's increased awareness of how food items are raised and harvested, be it a glass of milk, an ear of corn, a tilapia fillet, or a shrimp. For some consumers, it is important simply to know what chemicals (including hormones) are used in the production of their food; others have found ways to consume products that are biologically safe by depending on practices that cause minimal harm to the environment. These concerns are reflected in the growth in sales of organic food, 
which by 2010 reached $\$ 28.6$ billion, an increase of 21 percent in the past decade (Organic Trade Association 2011).

\section{State of Farmers Farming in the United States}

A plethora of research by anthropologists and other social scientists over the past six decades highlights trends in U.S. agriculture in the areas of production, distribution, and consumption, including studies of commodities, vertical integration, global and local food systems, and general issues of food access (Bonanno 1994; Friedmann 1993; Grey 2000; Heffernan and Constance 1994; Stull and Broadway2004). In the 1940s, Goldschmidt (1978) wrote about the rise of industrial agriculture in California and its negative impact on communities (Welch 2009). From the 1960s on, many farmers jumped on the pesticide treadmill with hopes of being able to farm better (Barlett 1989, 1993), and in some cases farmers ${ }^{2}$ were forced to get big or get out (Halweil 2004). Farmers struggled, many getting into debt too quickly and not able to make a go of it; some families were forced to sell off all or part of their farms, and others turned to having a spouse take an off-farm job to help meet some of the household obligations or delay bankruptcy (Barlett 1993). Farming is and always has been a hard way of life. As in the past, today's farmers and their families take on risks, play the odds, and each year, try to do better as they face what they cannot control: market prices, regulations, insects, fungi, drought, floods, animal, and avian infestations.

Every 5 years, the Census of Agriculture made available by the U.S. Department of Agriculture (USDA) reports on trends in U.S. agriculture. U.S. agriculture is characterized by the loss of farms, increased average farm size, increased use of hired part-time labor (including immigrant farm workers) coupled with increased mechanization (Lyson 2004; Welch 2009). In 2007, the number of farms increased in the United States for the first time since the Second World War (USDA 2009). The 2007 Census of Agriculture reported 2.205 million farms in the United States, an increase of 4 percent from 2002. However, the total land area in farming decreased by 2 percent. The number of small-scale producers grew dramatically during this period: farms under 50 acres grew to 853,000, a 15 percent increase between 2002 and 2000, and farms under 10 acres grew 30 percent to 232,000 (USDA 2009). In fact, by 2007, 60 percent of all farms in the United States reported less than $\$ 10,000$ in sales of agricultural products (USDA 2009). So whether it is in farm size or farm earnings, small seems to predominate current trends in U.S. agriculture. Additionally, 55 percent of the farmers reported a primary occupation other than farming, and among farmers under the age of 45 years, 81 percent worked off-farm. Women are gaining in recognition too. The number of women listed as principal farmers in 2007 increased to 14 percent from 11 percent in 2002. Interesting questions can be raised with these demographic trends. For example, why the increase in small-scale farmers and female farm operators; how did they acquire the land on which they farm; do they own the land; how much land are they farming; and how are they marketing their harvest? And most importantly, are they making it as full-time or part-time farmers? 
Yet for all the attention food, eating, cooking, and health have been getting over the years, farmers themselves (including ranchers) have not received equal attention. We hear about farm subsidies and the price of oil affecting the price of corn, but not how farmers contribute as a mainstay of society - they provide the raw materials that feed us. Today's farmers are no longer spring chickens. Their average age is 55 years, suggesting that farmers remaining in the industry are getting older and that fewer younger people are joining the profession (USDA 2007). The USDA comments "the fastest growing group of farm operators is those 65 years and older," increasing 22 percent from 2002 to 2007 (USDA 2007). To illustrate aging in farming, it is reported there were 54,147 farmers under the age of 25 and 289,999 farmers who were 75 years and over (USDA 2007). Interestingly, older farmers tend to raise beef cattle and reside in the U.S. south and west, while younger farmers raise just about anything and are found primarily in Indiana, Wisconsin, Pennsylvania, Minnesota, and Delaware (USDA 2007).

At the end of the day, the United States needs new farmers to emerge, for, each year, the national, state, and county average ages of farmers increase. So we must ask: who will be the future farmers, who will have the knowledge (cultural and practical) of how to farm on a small, medium, large, and industrial scale? A number of opportunities exist that may entice the up and coming generations to learn and be creative in farming, such as community gardens, school gardens, farm tours, cooking with chefs, volunteering on-farm, urban farming, home gardening, and rooftop agriculture (Goodall 2005; Lappé and Lappé 2002). Googling any one of these topics generates a list of researchers, projects, advocacy groups, and opportunities that work towards civic agriculture (Lyson 2004) where economics and the environment intersect with social justice to create a local, sustainable agriculture and food system (DeLind 2011; Giombolini et al. 2011).

\section{The State of U.S. Fishermen}

Fishermen (or watermen or fishers ${ }^{3}$ ) face fluctuations in species whether from overfishing, pollution, or climate change. Today, they face loss of market access because of the availability of less expensive imported seafood from industrial haulers. Moreover, fishermen contend they are hit with increasing regulations and low prices for their catch, leading to the potential loss of business, way of life, and cultural heritage. The average age for a commercial fisherman is 50 years, suggesting that as with farming, it is becoming harder for younger generations to join the ranks. Moreover, the CDC states that commercial fishing is one of the most dangerous occupations in the United States.

To harvest seafood commercially from a body of water, fishermen must be licensed and have the appropriate equipment with which to land (bring to shore) their seafood product. Over the years, sophisticated technology (radar, sonar, geographic information system) have helped commercial fishermen locate fish, but boat size, gear, and labor limit what a fisherman might land. Fishery regulations, federal and regional, also dictate how much of a particular kind of fish can be 
landed, as well as when it can be caught, for some fisheries are seasonal, with catch limits and quotas.

Just like small-scale farmers, who face dramatic changes in their rural landscapes as former urban dwellers moving to the countryside along with big box stores, traditional coastal communities and fishermen's coastal heritage are being transformed. Fishing communities face the loss of shore access as new housing and tourism developments take away waterfront access. It is difficult to say how many fishermen have left the business, and reliable national and state figures are challenging to find. Yet, for some communities the loss is substantial. Remaining commercial fishermen survive by cutting costs, limiting the number of boats they own and use, limiting the time they are out scrapping for fish (fuel prices are too high to wander) and doing anything else they can to stay afloat. Will it be enough for them to be able to fish 10 years from now?

The fishing industry is governed by layers of regulators at the international, national, regional, and county levels. The National Oceanic and Atmospheric Administration (NOAA) has broad responsibilities for protecting and regulating U.S. marine fisheries and fish populations (NOAA 2011). NOAA's National Marine Fisheries Service (NMFS) has both domestic and international responsibilities governing the economic benefits to the world's fisheries, the world's largest exclusive economic zone, from sustainable use and conservation of living marine resources. It is through fisheries management, law enforcement, and habitat conservation that NMFS protects and preserves living marine resources and their habitats. Together, NOAA and NMFS regulate U.S. marine fisheries; in other words, they can close a fishery down regionally and nationally. The MSA ${ }^{4}$ of 1976 created eight Regional Fishery Management Councils charged with preparing fishery management plans that are enforced by NMFS agents and the U.S. Coast Guard. "The National Marine Fisheries Services has been moving toward ecosystem management” (Clay and Olson 2008:144) with an emphasis on restoring depleting fish stocks, which has directly affected fishermen and fishing communities, at times, putting them out of business.

Decades of trying to meet the increasing demand for seafood has contributed to overfishing certain species. "The 2010 Status of Stocks Report identifies 48 overfished stocks and an additional 21 stocks, which have biomass levels so low they fall beneath the 'Minimum Stock Size Threshold' " (National Resources Defense Council 2011). As a result, the U.S. catch is declining, as fishermen take more fish out of the sea than can be replenished naturally. For fishermen, this is a hard blow to their income, way of life, and cultural heritage. In 2007, U.S. fishermen landed 9.3 billion pounds (or $\$ 4.2$ billion worth), the second smallest quantity in 20 years (Stoller 2009). A study conducted by the environmental think tank and economic analysis firm Ecotrust (2011) calculates that commercial fishermen in New England, South Atlantic, and Gulf of Mexico lost between \$162.4 and \$222.5 million in 2009 as a result of the overfishing that has left fisheries nationwide severely depleted. 
Regardless of scale, what will fishermen (commercial and recreational) catch in the future if the stocks continue to decline? If fishermen were paid more per pound, would they fish less? What is a socially just and economically viable plan to preserve a maritime culture and coastal heritage for a community and its fishermen? These environmental questions are related to long-term plans for protecting endangered fisheries such as snapper, grouper, and cod, which, in turn, would protect the remaining fishermen. Whether through catch limits, moratoriums on specific fisheries, or some management plan that puts an end to overfishing, NOAA and NMFS will be making difficult long- and short-term decisions, for without fish, it is hard to be a wild-caught commercial fisherman.

The public's increasing interest in consuming seafood has not gone unnoticed by all those participating in the seafood supply chain that tries to meet this demand. In 2005, Americans consumed 16.2 pounds $(7.3 \mathrm{~kg}$ ) of fish and shellfish per person (NOAA 2009a). Recent studies, however, predict global fisheries may collapse by mid-century if they are not managed more sustainably, which compounds the commercial fishermen's problems. While fishermen could be capitalizing on the increased demand for their product, the supply is not always readily available, or they are not permitted to fish for it, or the price per pound does not meet their fishing expenses. To add to the fishermen's difficulties, in 2009, the total seafood brought to shore in the United States for food and industrial purposes was 7.9 billion pounds, a decrease of 6 percent from the previous year (NOAA 2009b). The result of increasing demand coupled with decreased U.S. catch is that roughly 90 percent of the seafood used for human consumption is imported (NOAA 2009b).

Aquaculture, the production of farm-raised seafood and the fastest growing industry within the agricultural sector, is helping to take pressure off the wild-caught varieties of some species such as salmon, shrimp, tilapia, and trout. However, like other forms of intensive animal rearing, such as cattle feed lots and confined poultry and hog operations, it is not without environmental consequences, in particular, the amount of waste produced. "While many aquaculture systems are closed with no harmful output, open net cage fish farms and land-based fish farms can discharge significant amounts of wastewater containing nutrients, chemicals, and pharmaceuticals that impact on the surrounding environment” (World Wildlife Foundation 2011). In addition, fish raised in open net systems have been known to escape, which can play havoc with wild stocks of the same species.

\section{Marketing Fresh Farm and Seafood Products}

Most industrial and large-scale farmers specialize, whether in monocultures such as grain or livestock such as beef cattle, dairy cattle, hogs, and poultry. Because of the volume they produce, most industrial-scale farms sell wholesale. Their economy of scale is beyond what they could possibly sell directly to the consumer. By contrast, small- to medium-scale farmers who diversify their production system and whose economy of scale is much less than large- and industrial-scale farms often rely on direct marketing retail outlets. Direct markets include: farmers markets, 
community supported agricultures (CSAs), U-picks, roadside stands, and anything that does not include a non-farmer reselling a farmer's product. Of particular importance in these forms of marketing is the critical role the public plays by providing direct support to local farmers with their purchases. Furthermore, their popularity is growing: over the past 5 years, the number of farmers markets has increased by 60 percent, from 4385 in 2006 to 7175 in 2011 (USDA 2011b).

CSA is another example of a direct marketing option for small-scale and diversified farmers, whereby the public prepays for a share of the harvest and becomes a member, shareholder, or subscriber to the farm. Members share in the benefits and risks associated with production, creating a social responsibility with the people involved and ecological responsibility to the land. CSAs were first introduced to U.S. farmers in 1985, and by 2007, over 12,500 CSAs were in operation (USDA 2007). Given its prepayment structure, this direct marketing practice has been criticized as elitist because it excludes low-income households. As part of their CSA philosophy, some farmers have responded by reserving a percentage of their shares for low-income families, with the other shareholders subsidizing the share price, thus creating a food community that is not exclusive (Andreatta et al. 2008; Henderson and van En 2007).

Again, economies of scale and health-food regulations dictate where fishermen may sell their harvest. Regulations now require retailers to label seafood's country of origin and to identify it as wild-caught or farm-raised; some consumers even want to know what gear is used in catching the fish. Smaller retail venues that work directly with local fishermen are often able to provide a name, a story, and possibly a photo of the fishermen whose seafood is being sold or served.

Consumers have become increasingly concerned with the quality of imported seafood, and are looking for locally produced seafood products because of their higher standards of harvesting and postharvest handling. Marketing strategies that help consumers to get to know their fisherman and make it easier for consumers to seek out local fishermen or locate retail outlets and restaurants that support local fishermen are the newest trends. Branding local seafood products with logos also aids with product identification. The success of direct marketing for small-scale farmers at farmers markets and with CSA arrangements are now helping small-scale fishermen. Borrowing from the CSA model, newly established community supported fisheries (CSFs) are designed to put a fuller dollar in a fisherman's pocket by removing the middlemen. Since their conception in 2007, CSFs now number more than 50 direct marketing arrangements in the United States (Andreatta and Parlier 2010; Andreatta et al. 2011).

Much more work needs to be done on direct marketing and how it facilitates creating food communities. Where farmers and the public have been working together for decades, fishermen and the public have not had the same level of one-on-one partnerships. Farmers markets and other forms of direct marketing have enabled farmers to educate their customers to eat seasonally, and in return, their customers are paying a premium for fresh, quality local products. Something akin to this needs to take place among fishermen and their customers. 


\section{Commonalities among Fishermen and Farmers}

As has been discussed, there are a number of parallels between farmers and fishermen and their ways of life. Collectively, economic, political, environmental, cultural, and social factors continue to create challenges, but the very survival of U.S. farmers and fishermen, and in particular, small-scale producers and harvesters, is at stake. Although farmers know where they will harvest their crops or obtain livestock from their fields and pens, they do not always know how much will be available for harvest. Climate, weather, insects, fungi, labor, commodity price, input costs, and water (dried up wells, lack of rain, and flooding) contribute to the seasonal unknowns of how "successful" a farming family will be per commodity each year. No amount of experience guarantees a "successful” harvest.

Climate and weather conditions play havoc with fishermen too. Hurricanes, rough seas, and other wind events tell only part of the story confronting fishermen at sea, regardless of boat/vessel size. Equally important is water quality, for it is water that supports fishery habitats. Waters that are too cold, too hot, too salty, too polluted alter the condition of the habitat and stress the species. So although commercial fishermen must "track" down their harvest, they too face high input costs, especially with rising fuel prices. They face lower commodity prices because of competition from less expensive imported seafood. Some fishermen remain dependent on fisheries that are already overharvested or threatened, which limits their fishing abilities. Their successful harvest is based solely on what is available in the regulated "commons."

\section{Food Communities and Food Movements}

While one segment of the public is interested in knowing their farmer or fishermen by participating in some aspect of direct marketing, there are others who have taken a keen interest in growing and raising their own farm fresh products. Young and old are getting their hands into the earth and planting their own foodstuffs in their front and backyards. Victory Gardens were planted at homes and in public parks during the First World War and Second World War to reduce the pressure on the public food supply brought on by the war effort. As a movement, Victory Gardens became a part of daily life, something that everyone could partake in and feel as though they were contributing to the home, community, or to the war effort.

Today, we see a resurgence in food gardens, but quite possibly for different reasons. People are returning to the earth to source their own food (Belasco 1993; Henderson and van En 2007). Some plant to "know" where their food comes from, some plant to know what is in or not in their food, and others plant out of economic necessity, while still others are returning to their roots, having realized they do not want the culture to leave agriculture. Grassroots campaigns promoting gardens have sprung up in many shapes, sizes, and forms. Increasingly, urban/city and suburban agriculture is reshaping personal and community use of space, and often is challenging city ordinances by converting lawns, vacant lots, backyards, front yards, roof-tops, balconies, and parks into edible landscapes, some of which include community gardens. 2011 report there 
are 90 million households in the United States with a yard and garden and over 25 million that grow some of their own food (Doiron 2011). Recently, the profile of the home garden has been raised to a national level. In March 2009, First Lady Michelle Obama set a national example and planted a "Kitchen Garden" on the White House lawn, the first since Eleanor Roosevelt's, to raise awareness about healthy eating.

There are many wake-up calls of late related to the questions of where does our food come from and what impact it has on our personal health and the health of the environment. Food safety and food (in)security are two more areas of interest in understanding the agri-aqua food system. Food activists and advocates have been working toward getting the public back to basics as evidenced by the countless TV cooking shows, growing membership in the Slow Food movement, federal food vouchers redeemable only at farmers markets, and many other programs that help to create food communities. Furthermore, researchers and activists are raising awareness of those residing in food insecure households (Gottlieb and Joshi 2010). In America, millions of people rely on food pantries and shelters and must occasionally go without food. In 2009, 14.7 percent of American households were food insecure at least some time during the year. Between 2007 and 2009, there was a 44 percent increase in the number of households using food stamps, from 3.9 to 5.6 million households (USDA 2011a). Households also accessed additional assistance through USDA's 15 food and nutrition assistance programs. The Supplemental Nutrition Assistance Program (SNAP) benefits enacted as part of the 2009 stimulus package recorded a 27 percent increase in the SNAP caseload, up from 12.7 million in 2008 to 15.2 million in 2009. Food Policy councils are emerging at the community, state, and national levels as a way to address equitable access to nutritious food and to reduce food poverty and food deserts, where low-income people lack access to supermarkets with nutritious foods. Across the country, food movements are attempting to improve Americans' eating habits, as well as relying on locally produced products to help America's food producing/harvesting communities.

A pioneer in the field, Chef Alice Waters, dedicated countless hours for more than two decades to bring healthy food to school children in Berkeley, California. Her successes contributed to the national and local farm-to-school lunch programs that we see throughout the United States. And more initiatives are underway. For example, child-care centers are developing and maintaining seed-to-table programs with their gardens and edible school yards. Universities and colleges are getting involved in sustainability, campus gardens, food projects, and dining services (Barlett 2011). And the Department of Defense and USDA are working with the military to help returning soldiers and their families heal through gardening. Much more programming at the community level, involving people dedicated to bringing local fresh farm and seafood products to children and their families, is needed to maintain food communities, as well as sustain local fishermen and farmers.

The use of social media programs to connect food providers to the public through various websites and other forms of social technologies (blogging, Facebook, MySpace, LinkedIn, Tripadvisor, Foursquare, and Twitter) has gradually become the norm. There are local, regional, 
national, and international websites for beginning and advanced (seasoned) gardeners, farmers, fishermen, cooks, and chefs. In some cases, the sites serve as resources for information, and in others, they work as advertising for events or activities. For example, fishermen turned to social media after the BP oil spill to inform the public about its impact on the local fishing industry. Fishermen and farmers find it easier and, at times, less expensive to advertise online. For example, farmers may find it more efficient to advertise on Facebook or MySpace, or send out an e-newsletter to friends of the farm when blueberries are ready for U-pick or when corn mazes are ready for the public to visit, than to maintain an advertisement in the paper, radio, or TV.

\section{Concluding Thoughts}

Many of us who have been researching or contributing to U.S. farming, fisheries, and nutrition programs for the past few decades or more are now beginning to see the fruits of our efforts. However, this is not the time to become complacent. There is a need to empower the next generation of farmers and fishermen to become the keepers of local knowledge and practices. Farmers and fishermen are known to be resilient, adaptive, independent, and their own bosses, characteristics that keep them enjoying what they do as a way of life. However, when faced with perfect storms of high fuel prices, extreme weather conditions, or low commodity prices, it is no wonder younger family members prefer to sell the land or the boat and turn to other lines of work.

We must continue to ask questions of the agri-aqua food system. Will today's food movements continue to respond to food policies and regulations, environmental issues related to food production and resource use, and the social justice of who gets to eat, eat what, how much, and at what cost? How will the cultural aspects of production and consumption be maintained for future generations? Do smaller and local food producers and harvesters have a chance of making it in the 21 st century?

Food communities come about as a proactive response to the public's desire to reconnect with the earth by means of gardening, farming, fishing. Just as important, they allow consumers to make connections with food providers, specifically fishermen and farmers. CSFs are the newest direct marketing approach, only 3 years old, and the jury is still out as to how effective it will be for fishermen and fisheries. Will this new business model for fishermen achieve its goal of keeping them fishing for their livelihood, while also encouraging the public to learn about the fishermen and the seafood they consume? There are opportunities for young people to get involved in the food system, but they need educating about how to fish, garden, farm, and cook. Creating partnerships with food providers and the public, where stories and friendships are forged, may foster an appreciation and value for fresh local foods that will help to sustain fishermen, farmers, and the environment, without which we are without a sustainable community. 


\section{Notes}

1. An earlier version of this article was presented at the Society for Applied Anthropology annual meetings held in Seattle, Washington, March 30-April 2, 2011.

2. The official definition of a farm or ranch includes all places where $\$ 1,000$ or more of agricultural products were sold, or normally would have been sold (USDA 2009).

3. Fishermen, watermen, and fishers are the same. Regionally, in the United States, those who fish may refer to themselves or their occupation or be referred by others as one of the three terms listed. For this article, “fishermen” is used for consistency.

4. The Magnuson-Stevens Fishery Conservation and Management Act, Public Law 94-265 as amended (Magnuson-Stevens Act [MSA]) provides for the conservation and management of fishery resources within the U.S. exclusive economic zone (EEZ). It also provides for fishery management authority over continental shelf resources and anadromous species beyond the EEZ, except when they are found within a foreign nation's territorial sea or fishery conservation zone (or equivalent), to the extent that such sea or zone is recognized by the United States. MSA has been amended and/or reauthorized in 1981, 1983, 1989, 1991, 1996, and 2006 (NOAA 1998; Clay and Olson 2008).

\section{References Cited}

Andreatta, Susan, and Anne Parlier 2010 The Political Ecology of Small-Scale Commercial Fishermen in Carteret County, North Carolina. Human Organization 69(2):180-191.

Andreatta, Susan, Barry Nash, and Gretchen B. Martin 2011 Carteret Catch $^{\mathrm{TM}}$ : Promoting Local Seafood through Community and Business Partnerships. Human Organization 70(3):279-288.

Andreatta, Susan, Misty Rhyne, and Nicole Dery 2008 Lessons Learned from Advocating CSAs for Low-Income and Food Insecure Households. Southern Rural Sociology 23(1):1-33.

Barlett, Peggy 1989 Industrial Agriculture. In Economic Anthropology. Stuart Plattner, ed. Pp. 253-291. Stanford: Stanford University Press.

Barlett, Peggy 1993 American Dreams, Rural Realities: Family Farms in Crisis. Chapel Hill, NC: University of North Carolina Press.

Barlett, Peggy 2011 Campus Sustainable Food Projects: Critique and Engagement. American Anthropologist 113(1):101-115.

Belasco, Warren 1993 Appetite for Change. How the Counterculture Took on the Food Industry. Ithaca, NY: Cornell University Press.

Bonanno, Alessandro 1994 Introduction. From Columbus to Con Agra: the Globalization of Agriculture and Food. Lawrence, KS: University of Kansas Press. 
Centers for Disease Control and Prevention (CDC) 2011a U.S. Obesity

Trends. http://www.cdc.gov/obesity/data/trends.html, accessed August 11, 2011.

Centers for Disease Control and Prevention (CDC) 2011b Workplace Safety \& Health

Topics. http://www.cdc.gov/niosh/topics/fishing/, accessed August 11, 2011.

Clay, Patricia, and Julia Olson 2008 Defining "Fishing Communities": Vulnerability and the Magnuson-Stevens Fishery Conservation and Management Act. Human Ecology

Review 15(2):143-160.

DeLind, Laura 2011 Are Local Food and the Local Food Movement Taking Us Where We Want to Go? Or Are We Hitching Our Wagons to the Wrong Stars? Agriculture and Human Values 28:273-283.

Doiron, Roger 2011 Kitchen Gardeners. A Global Community of Cultivating

Exchange. http://kitchengardeners.org/message-candidates-listen-roger-gardener, accessed August 14, 2011.

Ecotrust 2011 Community Dimensions of Fisheries Catch Share Programs Integrating Economy, Equity, and Environment National Panel on the Community Dimensions of Fisheries Catch Share Programs, March 15.http://www.ecotrust.org/fisheries/NPCDFCSP_paper_031511.pdf, accessed 15, 2011.

Friedmann, Harriet 1993 The Political Economy of Food: A Global Crisis. New Left Review 197:29-57.

Gabaccia, Donna. 1998 Food Fights and American Values. In We Are What We Eat: Ethnic Food and the Making of Americans.Donna Gabaccia , ed. Pp. 122-148. Cambridge, MA: Harvard University Press.

Giombolini, Katy, Kimberlee Chambers, Sheridan Schlegal, and Jonnie Dunne 2011 Testing the Local Reality: Does the Willamette Valley Growing Region Produce Enough to Meet the Needs of the Local Population? A Comparison of Agriculture Production and Recommended Dietary Requirements. Agriculture and Human Values 28:247-262.

Goldschmidt, Walter 1978 As You Sow. Montclair, NJ: Allanheld, Osmun.

Goodall, Jane 2005 Harvest for Hope: A Guide to Mindful Eating. New York: Warner Books.

Gottlieb, Robert, and Anupama Joshi 2010 Food Justice. Cambridge, MA: MIT Press.

Grey, Mark A. 2000 Industrial Food Stream and Its Alternatives in the United States: An Introduction. Human Organization59(2):143-150. 
Halweil, Brian 2004 Eat Here. Reclaiming Homegrown Pleasures in a Global Supermarket. New York: W. W. Norton and Company.

Heffernan, William D., and Douglas H. Constance 1994 Transitional Corporations and the Globalization of the Food System. In From Columbus to ConAgra: The Globalization of Agriculture and Food. Alessandro Bonanno , Lawrence Busch, William H. Friedland, Lourdes Gouveia , and Enzo Mingione , eds. Pp. 29-51. Lawrence: University Press of Kansas.

Henderson, Elizabeth, and Robyn van En 2007 Sharing the Harvest: A Guide to Community Supported Agriculture. White River Junction, VT: Chelsea Green Publishing Company.

Lappé, Frances Moore, and Anna Lappé 2002 Hope's Edge. The Next Diet for a Small Planet. New York: Penguin Putnam Inc.

Lyson, Thomas 2004 Civic Agriculture: Reconnecting Farm, Food and Community. Medford, MA: Tufts University Press.

National Oceanic and Atmospheric Administration (NOAA) 1998 Magnuson-Stevens Fishery Conservation Act.http://www.st.nmfs.noaa.gov/st1/fus/fus98/msfcma-8.pdf, accessed August 14, 2011.

National Oceanic and Atmospheric Administration (NOAA) 2009a "NOAA Fisheries Economics of U.S.” Fisheries Office of Science and Technology. http://www.st.nmfs.noaa.gov/st5/publication/fisheries_economics_2009.html, accessed July 27, 2011.

National Oceanic and Atmospheric Administration (NOAA) 2009b Statistical Highlights Fisheries of the United States, 2009. Prepared by NMFS Fisheries Statistics Division. http://www.st.nmfs.noaa.gov/st1/publications.html, accessed July 26, 2011.

National Oceanic and Atmospheric Administration (NOAA) 2011 What Is NOAA?http://www.legislative.noaa.gov/policybriefs/What\%20is\%20NOAA\%202011\%20\%20FINAL.pdf, accessed August 15, 2011.

National Resources Defense Council (NRDC) 2011 NMFS Releases 2010 Status of Stock Report. Switchboard. Staff Blog.http://switchboard.nrdc.org/blogs/satkinson/nmfs_resleases_2010_status_of_s.html, accessed July 26, 2011.

Nestle, Marion 2002 Food Politics. How the Food Industry Influences Nutrition and Health. Berkeley: University of California Press.

Organic Trade Association (OTA) 2011 Organic Industry Survey 2011. Overview. http://www.ota.com/organic/mt.html, accessed July 21, 2011. 
Schlosser, Eric 2011 Why Being a Foodie Isn't "Elitist.” Washington Post, April 27. http;//www.washingtonpost.com/opinions/why-being-a-foodie-isnt-elitist/2011/04/27, accessed May 2, 2011.

Stoller, Gary 2009 Many Commercial Fishermen Are Hanging Up Their Nets. USA Today, April 9.http://www.usatoday.com/money/industries/food/2009-04-08-quit-commercial-fishing_N.htm, accessed July 27, 2011.

Stull, Donald, and Michael Broadway 2004 Slaughterhouse Blues: The Meat and Poultry Industry in North America. Belmont, CA: Thomson and Wadsworth Publishers.

United States Department of Agriculture (USDA) 2007 Census of Agriculture. National Agricultural Statistics Service.www.agcensus.usda.gov, accessed July 27, 2011.

United States Department of Agriculture (USDA) 2009 News Release. 2007 Census Shows

Growing Trends in U.S. Agriculture.www.nass.usda.gov/nh/growtrendspress.pdf, accessed July 25, 2011.

United States Department of Agriculture (USDA) 2011a Agricultural Marketing Service. National Farmers Market

Directory.http://www.ams.usda.gov/AMSv1.0/ams.printData.do?templateprintPage\&navID=\&page=, accessed August 8, 2011.

United States Department of Agriculture (USDA) 2011b Economic Research Service. The Economics of Food, Farming, Natural Resource and Rural America. Briefing

Room. http://www.ers.usda.gov/Briefing/FoodSecurity/, accessed August 14, 2011.

Welch, Rick 2009 Farm and Market Structure, Industrial Regulation and Rural Community Welfare: Conceptual and Methodological Issues. Agriculture and Human Values 26:21-28.

World Wildlife Foundation (WWF) 2011 Aquaculture Problems:

Pollution.http://wwf.panda.org/about_our_earth/blue_planet/problems/aquaculture/pollution/, accessed August 14, 2011.

\section{Biography}

Susan Andreatta is an associate professor at the University of North Carolina at Greensboro in the department of Anthropology where she maintains an active research program working with small-scale farmers and fishermen in North Carolina. 